\title{
Comparative Analysis Techniques and Molecular Epidemiology of Classical Swine Fever Viruses in the Asian Context
}

\section{アジア地域における豚コレラウイルスの比較解析技術と分子疫学}

\author{
Stuart D. Blacksell \\ Mahidol-Oxford Tropical Medicine Research Unit, Faculty of Tropical Medicine, Mahidol University, \\ Centre for Tropical Medicine, University of Oxford,
}

\begin{abstract}
Summary
Classical swine fever (CSF) is a highly contagious virus infection of swine caused by classical swine fever virus (CSFV). CSF infections cause significant economic impact and hardship throughout Asia. Improved understanding of the epidemiology of an infectious agent can provide options for the control of disease. Developments in technology have allowed the simplified PCR-mediated amplification of targeted genomic regions and the rapid deduction of nucleotide sequences which can be related to the geographical origin of individual disease outbreaks. This review describes the comparative analysis techniques and molecular epidemiology of classical swine fever viruses in the Asian context.
\end{abstract}

Keywords : Classical Swine Fever, Molecular epidemiology, Asia, Phylogeography, Pigs

\section{Introduction}

Classical swine fever (CSF) is a highly contagious virus infection of swine caused by classical swine fever virus (CSFV), a member of the genus Pestivirus, family Flaviviridae. Understanding of the natural history of an infectious agent can provide avenues for the control of disease. The characterisation of the agent's taxonomic status, evolutionary background and geographic distribution may present opportunities to trace disease outbreaks or develop control strategies. In the past 15 years, the application of phylogenetic and geographic-based techniques to examine relationships between and within groups of viruses has become more commonly undertaken with the advent of molecular biologybased tools such as PCR and automated nucleotide sequencing. Molecular techniques have enabled the development of exquisite levels of comparative analysis between viruses. In recent times, the molecular phylogeny of viruses has expanded rapidly, even to lower technology environments. Developments in technology have allowed the simplified PCR-mediated amplification of

Corresponding author :

Stuart D. Blacksell

Mahidol-Oxford Tropical Medicine Research Unit, Faculty of Tropical Medicine, Mahidol University, 420/6 Rajvithi Rd., Bangkok 10400, Thailand

E-mail : stuart@tropmedres.ac targeted genomic regions and the rapid deduction of nucleotide sequences.

\section{Virus genome}

The CSFV genome is a positive-sense single-stranded RNA molecule of approximately $12.3-\mathrm{Kb}$. The open reading frame (ORF) encodes a single polyprotein that is post-translationally processed into structural and non-structural proteins. Flanking the ORF are non-coding regions at the $5^{\prime}\left(5^{\prime} \mathrm{NCR}\right)$ and $3^{\prime}\left(3^{\prime} \mathrm{NCR}\right)$ ends of approximately $360-385$ and 228 bases, respectively.

\section{Conventional analysis of CSF virus isolates}

Pestiviruses has been classified into five major species on the basis of antigenic and genetic comparison ${ }^{1)}$. The CSF group of viruses comprises one species, as do the viruses of the border disease (BD) virus group. Bovine viral diarrhea (BVD) viruses have been divided into two separate groups, each having its own species. The fifth species is made up of atypical pestiviruses including a virus isolated from a giraffe ${ }^{1)}$. It has been suggested that the BD virus group be further divided into three species (i.e., total of seven species) on the basis of $\mathrm{N}^{\text {pro }}$ nucleotide sequence ${ }^{2)}$. Classical Swine Fever virus is recognised as having only one serotype. Distinctions based on in vitro growth and antigenic and genetic characteristics have been made to classify CSF viruses.

\section{In-vitro biotypes}

CSFV field isolates have been recognized as noncytopatho- 
genic viruses. Therefore, CSFV has been assayed by cell culture fluorescent- antibody technique, immunoperoxidase staining and genetic techniques such as RT-PCR. The development of the exaltation of Newcastle disease virus (END) diagnostic technology by Japanese researchers employed Newcastle Disease virus to enhance cytopathic effect (CPE) in CSF virus infected cell cultures. It was recognised that CSF viruses could be grouped into END-positive and END-negative strains ${ }^{3)}$. Another method for biologically discriminating CSF virus in vitro, is the ability of some virus isolates to cause $\mathrm{CPE}^{4,5,6,7)}$.

\section{Virus neutralisation}

The CSF virus neutralisation process is based on immunological reaction primarily between the E2 protein and its corresponding antibody. Differences in the strength of neutralisation titres by different CSF virus strains with monoclonal or polyclonal antibodies are recognised as a useful method of comparative virus strain analysis. Differences can occur in the neutralising ability of CSF virus strains of differing virulence ${ }^{8}$. Subsequently, virus neutralisation has also been used in an attempt to classify and characterise pestiviruses isolates into groups on the basis of virulence and species specificity ${ }^{9,10)}$. Nevertheless, because of the difficulties of in vitro growth and detection of CSF virus in cell culture, this method has largely fallen from favour following the development of CSF virus molecular-based methodologies.

\section{Analysis of viral antigens employing monoclonal antibodies}

Monoclonal antibodies (MAbs) have been used to discriminate pestiviruses into groupings on the basis of similar neutralisation reactions ${ }^{11)}$. The application of a characterised panel of 13 MAbs to discriminate 125 pestiviruses of various origins resulted in the grouping of CSF virus and BVD viruses/BD virus isolates ${ }^{11}$. Furthermore, heterogeneity between CSF virus isolates and the possibility of differentiation between CSF virus field and vaccine strains was also recognised ${ }^{10,12)}$. In a different study, Hess et al. ${ }^{13)}$ employed a small number of CSF virus and BVD viruses specific MAbs to group $90 \mathrm{CSF}$ virus field isolates originating from Germany. Using a panel of seventy-six anti-pestivirus MAbs, Paton ${ }^{9)}$ assessed sixty-six pestivirus isolates and, in conjunction with phylogenetic analysis results, suggested the formation of four pestivirus sub-groups of which one was the CSF virus subgroup. Reports of the comparison of Asian CSF virus strains by $\mathrm{MAb}$ analysis are limited to a single study that employed MAbs raised against $\mathrm{ALD}$ and $\mathrm{GPE}^{-}$strains to compare twenty Japanese CSF virus field strains ${ }^{14)}$. MAb analysis of pestivirus isolates has been largely superseded as a tool for the comparative analysis of CSF virus isolates by phylogenetic analysis. This has been mainly due to the exquisitely sensitive nature of the phylogenetic analysis techniques, and the previously described in vitro difficulties of working with pestiviruses. Furthermore, it is also recognised that the production of CSF virus-specific MAbs is difficult and timeconsuming ${ }^{15}$.

\section{Phylogenetic analysis}

The genetic separation of CSF virus is largely based on comparative nucleotide sequence data of a $190 \mathrm{nt}$ region of the E2 gene $^{16,17)}$. Similar groupings of CSF virus strains are also possible by analysis of the $5^{\prime}$-NCR $(150 \mathrm{nt})$ and the NS5B gene $(409 \mathrm{nt})^{17}$. Other recent reports of genetic typing of CSF virus, employing similar methodologies to the examination of the NS5B genomic region have concurred with the groupings proposed by Paton et $\mathrm{al}^{18)}$. A major effort to standardise the CSF virus genetic typing analysis methodology to prevent disparity in genotype reporting (i.e., oligonucleotide primers, nucleotide alignment and phylogenic algorithms), has been published in the report of Paton et al. ${ }^{18)}$. Contingent to this analysis procedure was the availability of reference nucleotide sequence data. This has become available in the form of a World Wide Web database, established at the European Community CSF Reference Laboratory based at the University of Hannover ${ }^{19,20)}$.

\section{Genetic typing taxonomy.}

The current nomenclature and genogroup composition for CSF virus genetic typing has been described by Paton et al. ${ }^{17)}$, based on a refinement of the groupings as originally proposed by Lowings et al. ${ }^{16)}$. A series of early reports described the comparative genetic analysis of the $5^{\prime}-\mathrm{NCR}$ and the E1/E2 and NS5B genes of European CSF virus isolates to demonstrate genetic relationships ${ }^{21,22,23)}$. Later reports compared historical and contemporary virus isolates from different parts of the world to classify the viruses into genetically-related groups (or genogroups $)^{16,24)}$. The basis for the current genetic typing of CSF virus strains is the separation of virus isolates into three major genogroups with further divisions into subgroups.

\section{Restriction fragment length polymorphism analysis.}

Restriction fragment length polymorphism (RFLP) analysis of RT-PCR generated CSF virus amplicons has been employed to provide a rapid method of analysis to differentiate CSF virus strains and related pestiviruses. The RFLP analysis of the 5'$\mathrm{NCR}$ of the related flavivirus, Hepatitis $\mathrm{C}$ virus (HCV), has been successfully applied to investigate the genotype and sub-genotype identity of $\mathrm{HCV}$ isolates from different geographic regions ${ }^{25}$. In the first application of such techniques for discrimination of pestiviruses, Vilček et al. ${ }^{23)}$ employed the restriction endonucleases (RE), $A v a$ I and $B g l$ I to RT-PCR-generated amplicons of the 5'NCR to differentiate ruminant and porcine pestiviruses. Other researchers have used RFLP, to discriminate between vaccine and "wild type" viruses. The RE, Bbr PI, was used for the analysis of 5'-NCR amplicons to successfully discriminate between CSF field and vaccine strain viruses of European origin ${ }^{26}$. Application of Pst I, Kpn I and Bgl I REs has been used to discriminate between the Russian produced CS and LK vaccines and reference CSF field strain viruses ${ }^{27}$. A simple method of RFLP analysis that provides an indicator of CSF virus genotype identity to the subgroup level has been developed in Thailand to reduce the 
necessity for nucleotide sequencing in smaller diagnostic laboratories $^{28)}$. RFLP analysis of the E2 gene amplicons by digestion with $A v a$ II, Ban II and Pvu II REs resulted in characteristic, genotype-specific cleavage products ${ }^{28)}$.

\section{Molecular analysis of CSF virus isolates to determine virulence} characteristics.

Despite a large number of investigations detailing the genetic characteristics of CSF virus isolates, as yet, there are no indications as to presence of characteristic "virulence markers" within the CSF virus genomes. Virulence markers in the $5^{\prime}$-NCR of the related pestivirus, BVD virus, have been suggested ${ }^{29)}$. While no such virulence markers have been discovered within the CSF virus genome, investigations are continuing using chimeric viral clones that incorporated gene deletions (such as the $N^{\text {pro }}$ ) to determine possible virulence sites ${ }^{30,31,32)}$. Virus replication kinetics in vitro and in vivo has also been described for 10 natural and cloned CSF viruses to characterise virulence attributes ${ }^{30)}$.

\section{Molecular epidemiology of Asian CSF viruses}

\section{South East Asia}

The distribution of CSFV genotypes in South East Asia is presented in Table 1. Studies of the distribution of CSFV genotypes in South East Asia have been conducted in Lao PDR, Vietnam, Thailand and Malaysia. In the Lao PDR, two studies have examined the phylogenetic relationships of the $5^{\prime} \mathrm{NCR}^{33)}$ and E2 gene $^{34)}$ of Lao PDR CSF virus samples. All Lao CSF viruses belonged to subgroups 2.1 and 2.2. There was a strong geographical relationship between CSF virus isolates from the Northern region (subgroup 2.1) and the Southern region (subgroup 2.2) of Lao PDR. As the viruses assessed in the studies were only collected over a two and half-year period, it was not possible to assess the level of temporal variation in Lao PDR CSF virus isolates. The majority of Lao CSF viruses belonged to subgroup 2.2. Clear phylogeographic clusterings were evident for subgroup 2.2 viruses originating from provinces in the Southern region, most notably in Champassak province. An important finding was that no subgroup 2.2 virus isolates were detected in the Northern region of Lao PDR. Of the isolates belonging to subgroup 2.1, originated from the Northern and Central regions none with detected in the Southern region of Lao PDR. The Northern region of Lao PDR is very mountainous with poor transport infrastructure. This natural isolation forms a natural barrier from other regions of Lao PDR. It is therefore not unexpected, that CSF virus isolates from these areas may be distinct, given the geographical isolation of this region which was verified by the absence of subgroup 2.2 viruses in the Northern region. The presence of subgroup 2.1 viruses in the central region is most probably is due to the movement of infected pigs or pork products to Vientiane City for sale. A study of the viral diseases of pigs in Vietnam during 1999 to 2003 found subgroup 2.1 and $2.2 \mathrm{CSF}$ viruses ${ }^{35)}$ which is the same as those found in Lao PDR ${ }^{28,36}$. Other countries in South
East Asia demonstrate a large number of CSFV genotypes. In Thailand, subgroup 1.1, 2.1, 2.2 and 3.4 CSF virus strains have been identified from historical and contemporary Thailand virus isolates Three viruses of Thai origin were shown to belong to genogroups 1 and $3^{37}$. Study of Malaysian CSF viruses by analysis of the $5^{\prime}$-NCR, E2 and NS5B genomic regions, determined that CSF virus samples from the 1980s belonged within genogroups 1.2 and $2.1^{16)}$.

\section{Northern/Eastern Asia}

In northern and eastern parts of Asia, studies have been conducted in China, Japan, Taiwan and Korea. The first report of the genetic characterisation of Chinese CSF virus isolates was during a comparison of the NS5B genetic region of world-wide CSF viruses ${ }^{18)}$. The Chinese "Wuhan" field isolate and C-strain vaccine were both determined to be members of genogroup $1^{18)}$. More recent phylogenetic studies compared the E2 region and have identified CSF virus isolates belonging to subgroups 1.1, 2.1, 2.2 and 2.3. ${ }^{38)}$. The majority of the CSF virus isolates belonged to genogroup $2(89.3 \%)$ with the viruses being almost equally divided between sub-genogroups 2.1 (48.1\%) and 2.2 $(41.2 \%)^{38)}$. Of most interest is the genetic composition of CSF viruses originating in Yunnan and Guangxi Provinces of China that share common borders with Lao PDR and Vietnam respectively. All virus isolates originating from Yunnan Province belonged to sub-genogroup 2.138). Somewhat surprisingly, CSF viruses belonging to a range of subgroups, 1.1, 2.1, 2.2 and 2.3, were detected in adjacent Guangxi Province ${ }^{38)}$. A recent study using 28 MAbs tested against Chinese-derived subgroup 1.1, 2.1, 2.2 and 2.3 virus collected between 1996 to 2006 demonstrated significant antigenic diversity ${ }^{39)}$. Analysis of the $5^{\prime} \mathrm{NCR}$ of a large number of Japanese CSF virus isolates collected during outbreaks from the years 1951 to 1986 revealed that these viruses belonged to genogroups 1, 2 and $3^{37)}$. In Taiwan, subgroups 2.1, 2.2, 3.4 have been detected ${ }^{40,41)}$ and in Korea subgroup 3.2 $2^{17)}(1988-1999)$ and 2.1 (2002-2003) 42 have been reported.

\section{Western Asia}

To date only one study has been performed in India to determine the genotype of CSFV causing disease. The study ${ }^{43)}$ examined $5^{\prime} \mathrm{NCR}, \mathrm{E} 2$ and NS5B gene from $16 \mathrm{CSFV}$ isolates from Assam, India and found that they all belonged to subgroup 1.1 and analysis in E2 and NS5B region placed the Indian isolates in a clearly separated clade within subgroup 1.1. These results are at odds with other areas of Asia which have multiple genotypes and hints at a closer link to a European source.

\section{Europe}

The majority of recent European CSF virus isolates belong to genogroup $2^{17)}$. The Western and Central European CSF viruses isolated in the early 1990's were members of the subgroup $2.3^{16,17,44)}$. Eastern European CSF virus isolates from the 1990's belonged to subgroups 2.2 and $2.3^{45}$. Analysis recent of Italian CSF virus indicated that the majority of early to mid 1990's 
Table 1. Summary of CSF virus genogroups found in Asia

\begin{tabular}{|c|c|c|c|}
\hline Region & Country & Sub-genotype & Reference \\
\hline Central/Northern Asia & China & $1.1,2.1,2.2,2.3$ & Tu et al. ${ }^{38)}$ \\
\hline Eastern Asia & Japan & $1.1,1.2,2.2,3.4$ & Sakoda et al. ${ }^{37)}$ \\
\hline Eastern Asia & Korea & 3.2 & Paton et al. ${ }^{17)}$ \\
\hline Eastern Asia & Taiwan & $2.1,2.2,3.4$ & Pan et al. ; Deng et al. ${ }^{40,50)}$ \\
\hline SE Asia & Lao PDR & $2.1,2.2$ & Blacksell et al. ; Blacksell et al. \\
\hline SE Asia & Thailand & $\begin{array}{l}1.1,3.3 \\
1.2,2.2,3.3\end{array}$ & $\begin{array}{l}\text { Parchariyanon et al. ; Parchariyanon et } \\
\text { al. ; Sakoda et al. }{ }^{28,36,37)}\end{array}$ \\
\hline SE Asia & Malaysia & $1.2,2.1$ & Lowings et al. ; Vilcek et al. ${ }^{16,24)}$ \\
\hline SE Asia & Vietnam & $2.1,2.2$ & Kamakawa et al. ${ }^{35)}$ \\
\hline Western Asia & India & 1.1 & Sarma et al. ${ }^{43)}$ \\
\hline
\end{tabular}

isolates belonged to subgroup 2.2 and $2.3^{46}$. Notably, the virus responsible for the large 1997/98 CSF outbreak in the Netherlands that spread to other areas of Europe was a member of the subgroup $2.1^{47,48)}$ and it is believed that this virus was newly introduced to the EU as this subgroup had not been detected since $1993^{46}$.

\section{Phylogeographic relationships between CSFV genotypes : opportunities and limitations for disease control.}

There is considerable diversity in the distribution of CSFV genotypes throughout Asia and the rest of the world (Table 1). Genotype 2 viruses have the widest distribution in Asia and are the exclusive genotype in Lao PDR and Vietnam. It is interesting to note the diversity of CSFV genotypes in Thailand and China, however while it is not entirely clear why this is the case, transboundry movement of infected animals may be the cause. Given the diversity of genotype distribution in Asia, the monitoring of CSFV genotypes following an outbreak is an excellent tool for the monitoring of transboundry disease. A good example is the speculation on the possible origins of subgroup 2.1 viruses responsible for the CSF outbreaks in Western Europe during the 1990 's that where thought possibly be of Asian origin ${ }^{17,49}$. However, molecular epidemiology can only be an effective tool if continued assessments of virus isolates from the region are performed due to the mutations that naturally occur within the RNA genome and the potential incursions of new virus strains by the uncontrolled trans-boundary movement of animals within the region. Low-cost methods for genetic typing of CSFV such as the use of RFLP $^{28)}$ may provide more appropriate and rapid methodologies for the assessment of field virus isolates in lowtechnology settings although further investigations are required to confirm the long-term usefulness of the proposed techniques.

Divergence in the selection of genetic regions and methods of CSF virus genetic analysis has lead to lack of cohesion and difficulties in the interpretation of results. Reports by Grieser-
Wilke and Paton ${ }^{20)}$ and Paton et al. ${ }^{17)}$ have recommended distance matrix and dendrogram generation algorithms (i.e., Maximum-Likelihood and Neighbor- Joining algorithms) for the comparative analysis of standardised genomic regions for genetic comparison (i.e., 5'-NCR, E2 and NS5B). While there is significant merit in their recommendations, these reports provided no meaningful justification for the endorsement of such methodologies. While these methods are widely employed, other methodologies for distance matrix and dendrogram generation are also available (i.e., Kimura 2-parameter and Jukes-Cantor and UPGMA). The advent of the web-based phylogenetic analysis hosted by the European Community CSF Reference Laboratory based at the University of Hannover utilizing their extensive reference strain database ${ }^{19,20)}$ should enable harmonisation of analysis methods.

\section{Acknowledgments}

SDB is funded by the Wellcome Trust of Great Britain

\section{References}

1) Becher, P., et al. : Genetic diversity of pestiviruses : identification of novel groups and implications for classification. Virology, 262, 64-71, 1999.

2) Becher, P., et al. : Genetic and antigenic characterization of novel pestivirus genotypes : implications for classification. Virology, 311, 96-104, 2003.

3) Kumagai, T., Shimizu, T. and Matumoto, M. : Detection of hog cholera virus by its effect on Newcastle disease virus in swine tissue culture. Science, 128, 366, 1958.

4) Kosmidou, A., Buttner, M. and Meyers, G. : Isolation and characterization of cytopathogenic classical swine fever virus (CSFV). Arch Virol, 143, 1295-1309, 1998.

5) Meyers, G. and Thiel, H.J. : Cytopathogenicity of classical swine fever virus caused by defective interfering particles. $J$ Virol, 69, 3683-3689, 1995. 
6) Mittelholzer, C., et al. : Generation of cytopathogenic subgenomic RNA of classical swine fever virus in persistently infected porcine cell lines. Virus Res, 51, 125-137, 1997.

7) Aoki, H., et al. : Characterization of classical swine fever virus associated with defective interfering particles containing a cytopathogenic subgenomic RNA isolated from wild boar. J Vet Med Sci, 63, 751-758, 2001.

8) Pirtle, E.C. and Mengeling, W.L. : Antigenic differences in two hog cholera virus strains. Am J Vet Res, 32, 1473-1477, 1971.

9) Paton, D.J.. et al. : A proposed division of the pestivirus genus using monoclonal antibodies, supported by crossneutralisation assays and genetic sequencing. Vet Res, 26, 92-109, 1995.

10) Wensvoort, G., et al. : Antigenic differentiation of pestivirus strains with monoclonal antibodies against hog cholera virus. Vet Microbiol, 21, 9-20, 1989.

11) Wensvoort, G., et al. : Production of monoclonal antibodies against swine fever virus and their use in laboratory diagnosis. Vet Microbiol, 12, 101-108, 1986.

12) Wensvoort, G., Terpstra, C. and de Kluyver, E.P. : Characterization of porcine and some ruminant pestiviruses by cross-neutralization. Vet Microbiol, 20, 291-306, 1989.

13) Hess, R.G., et al. : Identification of hog cholera viral isolates by use of monoclonal antibodies to pestiviruses. Vet Microbiol, 16, 315-321, 1988.

14) Nishimori, T., Yamada, S. and Shimizu, M. : Production of monoclonal antibodies against classical swine fever virus and their use for antigenic characterization of Japanese isolates. J Vet Med Sci, 58, 707-710, 1996.

15) Kamolsiriprichaiporn, S., et al : A comparison of the pathogenicity of two strains of hog cholera virus. 1. Clinical and pathological studies. Aust Vet J, 69, 240-244, 1992.

16) Lowings, P., et al. : Classical swine fever virus diversity and evolution. J Gen Virol, 77 (Pt 6), 1311-1321, 1996.

17) Paton, D.J., et al. : Genetic typing of classical swine fever virus. Vet Microbiol, 73, 137-157, 2000.

18) Bjorklund, H., et al. : Phylogenetic comparison and molecular epidemiology of classical swine fever virus. Virus Genes, 19, 189-195, 1999.

19) Dreier, S., et al. : A sequence database allowing automated genotyping of Classical swine fever virus isolates. J Virol Methods, 140, 95-99, 2007.

20) Greiser-Wilke, I., et al. : Structure and presentation of a World Wide Web database of CSF virus isolates held at the EU reference laboratory. Vet Microbiol, 73, 131-136, 2000.

21) Hofmann, M.A., Brechtbuhl, K. and Stauber, N. : Rapid characterization of new pestivirus strains by direct sequencing of PCR-amplified cDNA from the $5^{\prime}$ noncoding region. Arch Virol, 139, 217-229, 1994.

22) Lowings, J.P., et al. : Classical swine fever : genetic detection and analysis of differences between virus isolates. J Gen Virol, 75 (Pt 12), 3461-3468, 1994.

23) Vilcek, S., et al. : Pestiviruses isolated from pigs, cattle and sheep can be allocated into at least three genogroups using polymerase chain reaction and restriction endonuclease analysis. Arch Virol, 136, 309-323, 1994.

24) Vilcek, S., et al. : Genetic variability of classical swine fever virus. Virus Res, 43, 137-147, 1996.

25) Davidson, F., et al. : Survey of major genotypes and subtypes of hepatitis $\mathrm{C}$ virus using RFLP of sequences amplified from the 5'non-coding region. J Gen Virol, 76 (Pt 5), 1197-1204, 1995.

26) Vilcek. S. and Belak, S. : Classical swine fever virus : discrimination between vaccine strains and European field viruses by restriction endonuclease cleavage of PCR amplicons. Acta Vet Scand, 39, 395-400, 1998.

27) Zaberezhny, A.D., et al. : Differentiation between vaccine strain and field isolates of classical swine fever virus using polymerase chain reaction and restriction test. Dtsch Tierarztl Wochenschr, 106, 394-397, 1999.

28) Parchariyanon, S., et al. : Genetic grouping of classical swine fever virus by restriction fragment length polymorphism of the E2 gene. J Virol Methods, 87, 145-149, 2000.

29) Topliff, C.L. and Kelling, C.L. : Virulence markers in the 5 'untranslated region of genotype 2 bovine viral diarrhea virus isolates. Virology, 250, 164-172, 1998.

30) Mittelholzer, C., et al. : Analysis of classical swine fever virus replication kinetics allows differentiation of highly virulent from avirulent strains. Vet Microbiol, 74, 293-308, 2000.

31) Ruggli, N., et al. : Nucleotide sequence of classical swine fever virus strain Alfort/187 and transcription of infectious RNA from stably cloned full-length cDNA. J Virol, 70, 3478-3487, 1996.

32) Tratschin, J.D., et al. : Classical swine fever virus leader proteinase Npro is not required for viral replication in cell culture. J Virol, 72, 7681-7684, 1998.

33) Blacksell, S.D., et al. : Genetic typing of classical swine fever viruses from Lao PDR by analysis of the 5' non-coding region. Virus Genes, 31, 349-355, 2005.

34) Blacksell, S.D., et al. : Phylogenetic analysis of the E2 gene of classical swine fever viruses from Lao PDR. Virus Res, 104, 87-92, 2004.

35) Kamakawa, A., Ho, T.V. and Yamada ,S. : Epidemiological survey of viral diseases of pigs in the Mekong delta of Vietnam between 1999 and 2003. Vet Microbiol, 118, 4756, 2006.

36) Parchariyanon, S., et al. : Sequence analysis of E2 glycoprotein genes of classical swine fever viruses : identification of a novel genogroup in Thailand. Dtsch Tierarztl Wochenschr, 107, 236-238, 2000. 
37) Sakoda, Y., et al. : Genetic heterogeneity of porcine and ruminant pestiviruses mainly isolated in Japan. Vet Microbiol, 65, 75-86, 1999.

38) Tu, C., et al. : Phylogenetic comparison of classical swine fever virus in China. Virus Res, 81, 29-37, 2001.

39) Zhu, Y., et al. : Antigenic differentiation of classical swine fever viruses in China by monoclonal antibodies. Virus Res, 142, 169-174, 2009.

40) Deng, M.C., et al. : Phylogenetic analysis of classical swine fever virus isolated from Taiwan. Vet Microbiol, 106, 187-193, 2005.

41) Lin, Y.J., et al. : Complete sequence of a subgroup 3.4 strain of classical swine fever virus from Taiwan. Virus Genes, 35, 737-744, 2007.

42) Cha, S.H., et al. : Phylogenetic characterization of classical swine fever viruses isolated in Korea between 1988 and 2003. Virus Res, 126, 256-261, 2007.

43) Sarma, D.K., et al. : Phylogenetic analysis of recent classical swine fever virus (CSFV) isolates from Assam, India. Comp Immunol Microbiol Infect Dis. Epub ahead of print, 2009.

44) Stadejek, T., et al. : Genetic heterogeneity of classical swine fever virus in Central Europe. Virus Res, 52, 195-204, 1997.

45) Bartak, P. and Greiser-Wilke, I. : Genetic typing of classical swine fever virus isolates from the territory of the Czech Republic. Vet Microbiol, 77, 59-70, 2000.

46) Biagetti, M., Greiser-Wilke, I. and Rutili, D. : Molecular epidemiology of classical swine fever in Italy. Vet Microbiol, 83, 205-215, 2001.

47) Greiser-Wilke, I., et al. : Molecular epidemiology of a large classical swine fever epidemic in the European Union in 1997-1998. Vet Microbiol, 77, 17-27, 2000.

48) Widjojoatmodjo, M.N., et al. : Comparative sequence analysis of classical swine fever virus isolates from the epizootic in The Netherlands in 1997-1998. Vet Microbiol, 66, 291-299, 1999.

49) Hofmann, M. and Bossy, S. : Classical swine fever in 1993 in Switzerland : molecular-epidemiologic characterization of the virus isolate. Schweiz Arch Tierheilkd, 140, 365-70, 1998.

50) Pan, C.H., et al. : Phylogenetic analysis of classical swine fever virus in Taiwan. Arch Virol, 150, 1101-1119, 2005. 


\section{<和文要約 $>$}

\section{アジア地域における豚コレラウイルスの比較解析技術と分子疫学}

Stuart D. Blacksell

要 旨

豚コレラは，豚コレラウイルスによって起こる豚の伝染性のウイルス感染症である。豚コレラはアジアの至る所で甚大 な経済的損害の原因となる。感染因子の疫学的理解は, 疾病制御の選択肢を提供する。技術発展によって，標的遺伝子領 域の PCRによる増幅や, 疾病発生源の地理情報に関連させた塩基配列の迅速解析が可能となった。本総説では, アジア 地域における豚コレラウイルスの比較分析技術と分子疫学について述べる。

キーワード：豚コレラ, 分子疫学, アジア, 系統樹, 豚

\section{諸 言}

豚コレラは，フラビウイルス科ペスチウイルス属に属す る豚コレラウイルスによって引き起こされる豚の伝染性ウ イルス感染症である。疾病因子の分類, 進化的背景, 地理 的分布の特徵は, 疾病の追跡や制御戦略を展開するための 機会を示してくれる。この 15 年間で，群間及び群内のウ イルス相互関係を調べる系統発生及び地理情報を基盤とし た技術の応用が, PCR や自動化された核酸シーケンシン グ等の分子生物学的技術の出現によって一般的なものに なっていきている。分子生物学的技術は, ウイルス間の微 妙なレベルの比較解析を可能にした。近年では，技術レベ ルが比較的低いところでも, ウイルスの分子系統学が急速 に拡大している。技術発展は, 標的ゲノム領域の増幅と核 酸配列の迅速解析を可能とした。

\section{ウイルスゲノム}

豚コレラウイルスのゲノムは，約 12,300 塩基の一本鎖 プラス鎖 RNA である。オープンリーディングフレーム （ORF）は一本のポリ蛋白をコードしており，翻訳後に構 造蛋白質と非構造蛋白質に切断される。ORF の両端には, 約 360～385 塩基の $5^{\prime}$ 非翻訳領域と 228 塩基の $3^{\prime}$ 非翻訳領 域がある。

豚コレラウイルスの一般的な解析

ペスチウイルスは，抗原及び遺伝子の比較により 5 種に 分類される ${ }^{1)}$ 。豚コレラウイルス群は 1 種を形成し，羊の ボーダー病ウイルスも同様に 1 種である。牛ウイルス性下 痢ウイルスは大きく 2 群に分類され, それぞれに種がある。 5 番目の種は，キリンから分離されたウイルスを含む非定 型のペスチウイルスにより構成されている ${ }^{1)}$ 。また，ウイ ルス蛋白質 $\mathrm{N}^{\mathrm{pro}}$ の遺伝子配列に基づくと，羊のボーダー病
ウイルスはさらに 3 種（ペスチウイルス全体で 7 種）に分 けられる ${ }^{2)}$ 。豚コレラウイルスの血清型は一つである。豚 コレラウイルスの分類は, in vitroにおける複製，抗原性 及び遺伝的な特性に基づいて行われている。

\section{In vitro の生物型}

豚コレラウイルスの野外分離株は一般的に非細胞病原性 である。従って, 蛍光抗体法, 免疫ペルオキシダーゼ染色, あるいは RT-PCR 法のような技術を用いて検査されてき た。日本の研究者により開発された END 法は，豚コレラ ウイルスが感染した細胞においてニューカッスル病ウイル スの細胞変性効果 (CPE) が増強される現象を応用したも のである。豚コレラウイルスは END 陽性と END 陰性に 分けることができる ${ }^{3)}$ 。生物学的に区別される他のものと しては, 希に存在するCPEを引き起こすウイルスである ${ }^{4-7)}$ 。 ウイルス中和

豚コレラウイルスの中和は，主として E2 蛋白質とそれ に対する抗体との免疫反応に基づいている。単クローン又 は多クローン抗体を用いたウイルス中和の差異は, ウイル ス株の比較解析に有用な方法として認められている。中和 抗体価の差異は, 様々な毒力の豚コレラウイルス中和でみ られる。また, ペスチウイルスを毒力や種特異性に基づい た群に分類し特徴付ける目的でもウイルス中和が使われて いる。しかしながら, in vitro の増殖や検出が難しいために, この方法は分子生物学的技術の開発の後続するようになっ ている。

\section{単クローン抗体を利用したウイルス抗原の解析}

単クローン抗体は，中和反応に基づいたペスチウイルス の識別に利用されている。由来の異なる 125 株のペスチウ イルスを識別可能な 13 種類の単クローン抗体を用いた抗 体パネルによって，豚コレラウイルスと牛ウイルス性下痢 ウイルス/ボーダー病イルスの群に分けることができる ${ }^{11}$ 。 
さらに，豚コレラウイルスの非同一性や，野外ウイルスと ワクチン株を識別する可能性も認められている ${ }^{10,12)}$ 。Hess らは，ドイッで分離された豚コレラウイルス野外分離株 90 株の分類にわずか数種類の豚コレラウイルス特異的及 び牛ウイルス性下㾥ウイルス特異的単クローナル抗体を用 いている ${ }^{13)}$ 。Paton らは, 76 種類の抗ペスチウイルス単ク ローン抗体のパネルを用いてペスチウイルス分離株 66 株 を系統解析の結果とともに評価し，ペスチウイルスが 4 亜 群を形成し，うち一つが豚コレラウイルス亜群であること を提唱した ${ }^{9)}$ 。単クローン抗体によるアジア地域の豚コレ ラウイルスの比較に関する報告は, ALD 株と $\mathrm{GPE}^{-}$株に 対する単クローン抗体を用いた日本の豚コレラウイルス野 外分離 20 株を比較した研究に限られている ${ }^{14)}$ 。ペスチウ イルスの単クローナル抗体を用いた解析は，主として系統 解析による豚コレラウイルス分離株の比較解析に取って代 わられた。これは主に, 系統解析技術が高感度であること, ペスチウイルスに関する in vitro の操作が煩雑であること が原因となっている。また, 豚コレラウイルス特異的単ク ローン抗体の作成は難しく，時間もかかるということも理 由である ${ }^{15)}$ 。

\section{系統解析}

豚コレラウイルスの遺伝的分類は，主に E2 遺伝子領域 内の 190 塩基の配列比較に基づいている ${ }^{16,17)}$ 。同じような 分類が， $5^{\prime}$ 非翻訳領域 (150 塩基) と NS5B 遺伝子領域 (490 塩基）の解析によって可能である。NS5B 遺伝子領域の解 析と同じ手法を用いた豚コレラウイルスの遺伝子型に関す る最近の報告は, Paton らによって提案された遺伝子型別 と一致する。プライマー, 核酸アライメントあるいは系統 分類のアルゴリズムに起因する遺伝子型の相異を防ぐため に豚コレラウイルスの遺伝子型の解析方法を標準化しよう という努力が Paton らによってなされている。これには, 参照となる核酸配列デー夕必要となる。ハノーバー大学に 拠点を置く欧州共同体豚コレラリファレンスラボラトリー で確立された World Wide Web データベースから利用可能 である ${ }^{19,20)}$

\section{遺伝子型別分類}

豚コレラウイルスの遺伝子型別の命名法及び群構成は, Paton らによって提示されており ${ }^{17)}$, Lowingsらによる群 分けの再編成の提案に基づいている ${ }^{16)}$ 。初期の一連の報告 では, ヨーロッパの豚コレラウイルス分離株の $5^{\prime}$ 非翻訳 領域, E1/E2 及び NS5B 遺伝子領域の比較遺伝解析につい て述べられている ${ }^{21-23)}$ 。その後の報告では, ウイルスを遺 伝的に関連する集団に分類することを目的に，異なる地域 で分離された過去及び現在のウイルス株を比較している ${ }^{16,24)}$ 。豚コレラウイルスの現在の遺伝子型は, 亜型への分

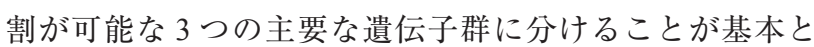

なっている。

\section{制限酵素切断長多形解析}

RT-PCR によって得られた豚コレラウイルスの遺伝子増 幅産物の制限酵素切断長多形 (RFLP) 解析は, 豚コレラ ウイルスと同属の他のペスチウイルスを区別するための迅 速解析法として使われている。ペスチウイルスと同じくフ ラビウイルス科に属する C 型肝炎ウイルスの 5' 非翻訳領 域の RFLP 解析が，地理的に異なる C 型肝炎ウイルスの 遺伝子型や遺伝子亜型の相異の調査に適用されている ${ }^{25)}$ 。 ペスチウイルスを識別するこの技術の最初の応用として, Vilček らは反匏動物のペスチウイルスと豚のペスチウイル スを区別するために制限酵素 $A v a \mathrm{I}$ 及び $B g l \mathrm{I}$ を $5^{\prime}$ 非翻訳領 域の RT-PCR 増幅産物に適用した。他の研究者もワクチン と野生型のウイルスを識別するために RFLP 解析を用いて いる。制限酵素 BbrPI が，ヨーロッパ由来の豚コレラ野外 株とワクチン株を区別するための $5^{\prime}$ 非翻訳領域の増幅産 物の解析に用いられている ${ }^{26)}$ 。制限酵素P Pst I, KpnI 及び $B g l \mathrm{I}$ は，ロシアで製造された CS 及び LK ワクチンと豚コ レラ野外標準株を区別するために使われた ${ }^{27)}$ 。規模の小さ な診断施設における核酸シーケンスの必要性を減らすため に，亜型レベルで豚コレラウイルス遺伝子型の相異がわか る簡単な RFLP解析法が, タイで開発された ${ }^{28)}$ 。制限酵素 $A v a \mathrm{II}, B a n \mathrm{II}$ 及び PvuII で消化する $\mathrm{E} 2$ 遺伝領域増幅産物の RFLP 解析は，遺伝子型特異的な切断パタンを示すという 結果となった ${ }^{28)}$ 。

\section{病原性に係わる豚コレラウイルスの分子生物学的解析}

豚コレラウイルスの遺伝的性状を詳述する数多くの調査 があるにもかかわらず，今のところ豚コレラウイルスゲノ ム中に特徴的な「病原マーカー」が存在するという証拠は ない。同属の牛ウイルス性下痢ウイルスでは 5'非翻訳領 域における病原マーカーが提案されている年。豚コレラウ イルスのゲノムの中にこのような病原マーカーは見つかっ ていないが, 病原部位を決定するために $\mathrm{N}^{\mathrm{pro}}$ などの遺伝子 に欠損を組み込んだキメラウイルスを使った研究が続いて いる ${ }^{30-32)}$ 。毒力の特性をみるために, 野外ウイルス 10 株 及びクローンウイルスを用いて in vitro 及び in vivoにおけ るウイルス複製の動態が調べられている ${ }^{30)} 。$

\section{アジアの豚コレラウイルスの分子疫学}

\section{東南アジア}

東南アジアにおける豚コレラウイルスの遺伝子型の分布 を表 1 に示した。東南アジアの豚コレラウイルスの遺伝子 型の分布についての研究が, ラオス, ベトナム, タイ及び マレーシアで行われている。ラオスでは, 豚コレラウイル スの $5^{\prime}$ 非翻訳領域と E2 遺伝子の系統発生的関係を調査し た 2 つ研究がある ${ }^{33,34)}$ 。ラオスで分離された豚コレラウ 
イルスは 2.1 及び 2.2 亜群に属していた。ラオス北部で分 離された豚コレラウイルス（2.1 亜群）と南部で分離され たウイルス (2.2 悪群)との間に強い地理的関与がみられた。 その研究で評価されたウイルスは 2 年半の間に収集された ものなので, ラオスの豚コレラウイルス分離株における時 間的変化を評価することは不可能であった。ラオスの豚コ レラウイルスの大部分が 2.2 亜群に属した。南部，特に Champassak 区に由来する 2.2 亜型のウイルスで系統地理 的な群形成が明白であった。ラオス北部で 2.2 覀型のウイ ルスが検出されないことは重要な発見である。北部または 中部に由来する 2.1 业型に属する分離株のうち, ラオス南 部で検出されたものはなかった。ラオス北部は山岳部であ り, 物資輸送基盤にそしい。この天然の隔離が, ラオスと 他地域との天然の防壁を形成している。従って, それら地 域の豚コレラウイルスは分断され，北部に 2.2 覀型が存在 しないことで裏付けられる地理的な隔離がもたらされてい ると考えることもできる。中部の 2.1 覀型の存在は, 売買 のための Vientiane 市への感染豚又は豚肉の移動によるも のがほとんどである。1999 年から 2003 年にかけてのべト ナムにおける豚のウイルス疾病の研究によれば, 豚コレラ ウイルス 2.1 及び 2.2 亜型が見つかっており ${ }^{35)}$, ラオスで 見つかったものと同じである ${ }^{28,36)}$ 。東南アジアの他の国で は, 数多くの豚コレラウイルス遺伝子型が示されている。 タイでは, 過去及び現在の豚コレラウイルス分離株から, 1.1，2.1，2.2 及び 3.4 亜型のウイルスが見つかっている。 夕イ由来の 3 株は, 遺伝子型 1 及び 3 に属していることが 示された ${ }^{37)}$ 。 $5^{\prime}$ 非翻訳領域, E2 及びNS5B 遺伝子領域の 解析によるマレーシアの豚コレラウイルスの研究によれ ば, 1980 年代の豚コレラウイルスが遺伝子型 1.2 及び 2.1 に属していることがわかっだ ${ }^{16)}$ 。

\section{アジア北東部}

アジア北東部においては, 中国, 日本, 台湾及び韓国で研 究がなされている。中国の豚コレラウイルス分離株の遺伝 的性状の最初の報告は, NS5B 遺伝子領域の比較である ${ }^{18)}$ 。 中国の野外分離株である“Muhan”とワクチンである C 株 がともに遺伝子型 1 に属することが解った ${ }^{18)}$ 。近年の系統 発生の研究では E2 遺伝子領域が比較されており, 1.1, 2.1, 2.2 及び 2.3 に属する豚コレラウイルスが見つかっている 38)。豚コレラウイルス株の大多数が遺伝子型 2 に分類され $(89.3 \%)$ ，さらに 2.1 亜型 $(48.1 \%)$ と 2.2 亜型 $(41.2 \%)$ にほとんど等しく分けられた ${ }^{38)}$ 。ラオス及びベトナムとの 共通の国境を有する中国の Yunnan 区と Guangxi 区に由来 する豚コレラウイルスの遺伝的構成に大きな関心がもたれ る。Yunnan 区のウイルス分離株は, 2.1 亜型に属していた ${ }^{38)}$ 。 驚いたことに，1.1，2.1，2.2 及び 2.3 亜型に属する数種の豚 コレラウイルスが隣接の Guangxi 区で検出された ${ }^{38)}$ 。2 28 種
の単クローン抗体を用いた最近の研究は, 1996 年から 2006 年にかけて収集された $1.1 ， 2.1 ， 2.2$ 及び 2.3 西型の中国由来 の各ウイルスにおける抗原の多様性を示している ${ }^{39)}$ 。日本 においては，1951 年から 1986 年までの流行中に収集された 豚コレラウイルスの多くが $5^{\prime}$ 非翻訳領域の解析によって遺 伝子型 1,2 及び 3 に属することが明らかにされた ${ }^{37)} 。$ 台 湾では，2.1，2.2 及び 3.4 亜型が検出されており ${ }^{40,41)}$, 韓国 では 1988〜1999 年にかけての 3.2 亜型 ${ }^{17)}$ と 2002 2003 年 における 2.1 亜型 $^{42)}$ が報告されている。

\section{アジア西部}

今日までに, 豚コレラウイルスの遺伝子型を決定した研 究はインドにおける一つだけである。この研究は, インド の Assam で分離された豚コレラウイルス 16 株の 5' 非翻訳 領域, E2 及び NS5B 遺伝子を調査したものである。その 結果, 全て 1.1 亜型に属すること, E2 及びNS5B の解析 によってそれらインドの株が 1.1 亜型のなかでも明瞭に区 別された集団を形成することが明らかになった。この結果 は，様々な遺伝子型をもち，ヨーロッパ由来との繋がりを もつアジアの他地域のものとは異質である。

ヨーロッパ

近年のヨーロッパの豚コレラウイルス分離株の大多数が 遺伝子型 2 に属する ${ }^{17)}$ 。1990 年代初期のヨーロッパ西部及 び中部の豚コレラウイルス分離株は 2.3 亜型であった ${ }^{16,17,44)}$ 。 1990 年代のヨーロッパ東部の豚コレラウイルス分離株は 2.2 及び 2.3 覀型に属していた ${ }^{45)}$ 。イタリアの豚コレラウ イルス分離株の解析は, 1990 年代初期から中期にかけて その大部分が 2.2 及び 2.3 亜型に属していることを示して いる ${ }^{46)}$ 。1997 年から 1998 年にかけてオランダで大流行し, ヨーロッパの他地域まで拡大したウイルスは 2.1 亜型であ $\eta^{47,48)}, 1993$ 年以来検出されなかったこの亜型は近年ヨー ロッパに再移入されたと考えられている ${ }^{46)}$ 。

\section{豚コレラの遺伝子型と地理的関係 : 疾病管理の機会と限界}

アジアやその他の地域をとおして, 豚コレラウイルス遺 伝子型の分布にはかなりの多様性がある（表 1)。遺伝子 型 2 のウイルスはアジアに広く分布しており， ラオスやべ トナムでは特に独占的な遺伝子型である。タイや中国にお ける豚コレラウイルス遺伝子型の多様性は興味深い。しか しながら, 必ずしも症例であることが明らかではないので, 感染動物の越境移動が原因であるかもしれない。アジアに おける遺伝子型の分布の多様性に関連して, 豚コレラウイ ルスの遺伝子型のモニタリングは, 疾病の越境をモニタリ ングするための優れたツールである。良い例としては，恐 らくはアジア起源であろう 1990 年代のヨーロッパ西部で 流行した 2.1 覀型の豚コレラウイルスの起源に関する推察 
である ${ }^{17,49)}$ 。RNA ゲノム中に自然に起きる突然変異や，無 法な動物の越境移動による新たなウイルスの潜在的な侵入 にしかるべき分離ウイルスの継続的な評価が実施されるな らば, 分子疫学は有効なツールである。新たに提案された 技術の長期有用性を確認するためにさらなる調査が必要と されるが, RFLP 解析 ${ }^{28)}$ のような豚コレラウイルスの低コ ストの遺伝子型別法は, 技術レベルの低い環境で野外ウイ ルス分離株を評価する適切かつ迅速な方法になる。

遺伝子領域やウイルス遺伝子解析法の相違は, 結果の結 合の欠如と解釈の難しさを招く。Grieser-Wilke と Paton ${ }^{20)}$ 及び Peton ら ${ }^{27)}$ は, 標準遺伝子領域（例えば，5'非翻訳領 域，E2 及び NS5B など）の比較解析のために遺伝子距離
行列及び樹状発生アルゴリズム（例えば，最尤アルゴリズ ムや近隣接合アルゴリズムなど）の使用を推奨している。 彼らの提案には十分なメリットがあるが，このような方法 論を是認する意義のある説明は彼らの論文にはなかった。 これらの方法は広く利用されているが, 遺伝子距離行列や 樹状発生解析に他の方法が利用可能である（例えば, キム ラの 2 パラメーターや Jukes-Cantor や UPGMA など)。ハ ノーバー大学に本拠を置く欧州共同体豚コレラリファレン ス・ラボラトリーによって構築されたウェブベースの系統発 生解析の提供は, 広範囲に亘る標準株のデータベース ${ }^{19,20)}$ を利用する解析方法の統一化を可能とするであろう。 